\title{
A Question of Quality: How Authors and Editors Perceive Library Literature
}

\author{
Barbara L. Floyd and John C. Phillips
}

\begin{abstract}
Librarians with faculty status are expected to do research and publish just as their teaching colleagues do. But unlike teaching faculty, most librarians have neither flexible work schedules nor nine-month contracts that are conducive to ongoing research and publication. This means that the requirement to publish in order to be a successful academic often competes with the requirement to perform daily work in order to be a successful librarian. One of the reasons the authors undertook this study was to examine whether the pressure to publish on most academic librarians has an impact on the quality of the literature appearing in library journals. Authors and editors of twenty-two library journals were surveyed to see how both sides of the publishing equation feel about the quality of their end product. This study reveals interesting findings about both editors and authors of library literature, and concludes with suggestions for improving the publishing process.
\end{abstract}

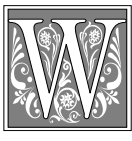

ith the attainment of faculty status by many academic librarians in the late 1960 s and early 1970s came the requirement to perform equally with teaching faculty. Of the three traditional areas of effort by academics-teaching, research, and service-librarians have the most difficulty fulfilling the requirement for research. Failure to publish is the most frequent reason for denying tenure to librarians. ${ }^{1}$ Despite the obvious importance of publishing to the careers of most academic librarians, few are given the time and resources to conduct ongoing, indepth, and successful research. ${ }^{2}$

This article examines whether the pressures felt by librarians to publish in order to be successful academics within the constraints imposed by their institutions are affecting the quality of what appears in library literature. By surveying authors who have published in academic library journals and the editors of those journals on their perceptions of the pressure to publish and the overall quality of our professional literature, the authors of this article hope to shed some light on the

Barbara L. Floyd is Associate Professor of Library Administration and University Archivist at the University of Toledo Libraries; e-mail:LBR0008@UofT01.utoledo.edu. John C. Phillips is Associate Professor of Library Administration and Map Librarian at the University of Toledo Libraries; e-mail: jphilli@utnet.utoledo.edu. 
questions of who is publishing and why. In addition, the authors will discuss whether the current process for producing scholarly publishing in the library profession affects the quality of those publications.

\section{Background}

Research and Publication in the Academy: Some Historical Developments

Historically, research and publication by faculty at American institutions of higher education have gone through several stages. During the colonial period, the college, with its strong British roots, focused on the student. ${ }^{3}$ The emphasis was on building character and preparing students for civic and religious leadership. Professors were not hired for their scholarship but, rather, for their commitment to moral and spiritual development. In the early nineteenth century, basic research began to take hold on college campuses. Scientific research emerged, and America's colleges and universities adopted the German approach to scholarship, emphasizing research and experimentation. By the turn of the century, research and graduate education increasingly influenced the development of the model for the modern university. For example, in 1895, the president of the newly formed University of Chicago could require each new faculty member to sign an agreement stating that promotions in rank and salary depended mainly upon their research accomplishments.

In the twentieth century, the importance of research to faculty careers took on even greater importance with the influx of money for government-sponsored research during World War II. Government research grants were needed to help fund the huge and expensive modern university. Government funding for research, as well as funding by private and nonprofit institutions, continued to increase during the five decades following the war.

In a 1969 survey conducted by the Carnegie Foundation for the Advance- ment of Teaching, 21 percent of faculty members strongly agreed that it was difficult to achieve tenure without publishing. By 1989, that number had doubled to 42 percent. ${ }^{4}$ As the mission of higher education changed and expanded, the standards used to measure academic prestige began to narrow. Promotion and tenure decisions were closely tied to research and publication, and young faculty members found these activities more rewarding in terms of status and money than teaching.

The relative merits of research and publication are being questioned, by not only faculty members but also critics of higher education. Many perceive that the emphasis on research is adversely affecting the quality of teaching, and some critics believe it is affecting the quality of publications themselves. As Oscar Handlin said, "the flow of print, often pointless but sustained by grants and by professional inertia, raises the tide of mediocrity and befogs the goals of scholarship." 5 Dennis P. Carrigan contends that the race for quantities of publications has led to "outright fraud in the reporting of the results of investigations." A proliferation of outlets for scholarly publishing has meant an increasing demand for manuscripts, perhaps at the expense of quality. A national survey of faculty conducted in 1989 found that even the faculty doing the publishing are skeptical about what is being produced, with more than a third replying they felt publications were merely counted, not evaluated for quality, when reviewed during personnel decisions. $^{?}$

\section{Librarians As Faculty}

Librarians began to acquire faculty status-and along with it, the concomitant requirements for publishing - in the late 1960 s and early 1970 s. In 1971, the University Libraries Section of the Association of College and Research Libraries (ACRL) endorsed the idea and developed "Standards for Faculty Status." The stan- 
dards prescribed by ACRL for librarian faculty status were similar in tone and content to those governing teaching faculty. The major points were professional responsibility, self-determination, and the opportunity for promotion, tenure, and sabbaticals. Further, the ACRL standards mandated that if librarians were to have faculty status, they were to fulfill the traditional academic three-pronged mission of teaching, research, and service on a par with their teaching counterparts. In the years following issuance of the ACRL standards, 67 percent of colleges and universities granted faculty status to librarians. $^{8}$

However, although required to achieve in each of the three traditional areas of faculty responsibility, librarians then and now face obstacles in conducting research that most other faculty do not. Primary among them is the forty-hour workweek and twelve-month contract. It is difficult to engage in research within these constraints. According to Emily Werrell and Laura Sullivan, "most academic librarians work under twelve-month contracts, do not receive salaries equal to the teaching faculty with the same rank, do not enjoy a flexible work day and week, and are not provided the compensatory release time necessary for them to contribute in a scholarly manner to their field." 9 The result is that some librarians view scholarship as an additional burden on their jobs rather than an integral part of them. Others see a conflict between service to patrons and research and publication expectations, and insist that if librarians are engaged in research, library service suffers. Despite the obstacles to getting works published, the most frequent reason librarians are denied tenure is a failure to conduct research and publish. ${ }^{10}$

In addition to the mere fact of publishing is the issue of the quality of what is published. Are librarians with hectic schedules and little time for research able to produce high-quality works? How does our profession feel about the qual- ity of library literature? Do we attempt to gauge quality when we judge our peers during personnel reviews, or is the quantity of published articles the primary factor by which we judge?

\section{Reasons for Study}

The attainment of faculty status for librarians at the University of Toledo (UT) followed a course similar to that at other institutions. During the early 1970s, library faculty members established guidelines to be used in making decisions on annual evaluations, promotions, and tenure. Those guidelines conformed to ACRL standards, and called for evaluating a faculty member's performance in teaching, scholarship, and service. However, despite faculty status, the UT librarians retained their twelve-month contracts and forty-hour workweeks without a clear

\section{The standards prescribed by ACRL for librarian faculty status were similar in tone and content to those governing teaching faculty.}

policy for release time for research. They are eligible for sabbatical leaves, but only once every seven years and only after attaining tenure.

The authors of this article became interested in investigating publishing by academic librarians as a result of having served on several library committees responsible for decisions on merit rewards, contract renewals, promotions, and tenure. Although the authors had responsibility for these decisions affecting their colleagues' careers, often they lacked relevant information or appropriate guidelines for making informed decisions on research and publication. ${ }^{11}$ For example, only in recent years have librarians been required to submit copies of their publications for evaluation. Hence, quality was not judged at all prior to this requirement, and even after this requirement was added, the committees lacked guidance on how to judge quality. Indeed, the quantity of publica- 
tions continues to take precedence over quality. Another area of concern that gave rise to this study was that of an author's qualifications to write on a chosen topic. Unlike some departments at UT that require outside peer review of scholarship as part of a faculty member's evaluation (which takes into consideration the qualifications of an author to write on a topic), such qualifications are not considered in the University Libraries' review process. Although librarianship is broader in scope than many academic disciplines, the authors nonetheless began to question whether evaluation committees should expect research relevant to the field in which the librarian works. They also wondered how other institutions assess qualifications for authorship.

\section{One stated that the majority of library literature should be "stillborn," and some journals serve as vanity presses for librar- ians who need to publish.}

But rather than look at the issue of quality of library literature only as it relates to personnel evaluations, the authors wanted to delve deeper into the issue. Specifically, they wanted to know more about who was publishing, what the rates of manuscript acceptance and rejection were, and how those who both published and served as gatekeepers for publications felt about the quality of academic library literature.

\section{Methodology}

To research the issue of quality in academic library publishing, the authors of this study surveyed both journal editors and journal authors to examine both sides of the publishing equation. From the periodicals indexed in Library Literature, the authors selected journals aimed at academic libraries, excluding specialized journals for community college, law school, and medical college libraries. Also excluded from the study were foreign pub- lications, state and regional newsletters, and journals consisting exclusively of library material reviews. To facilitate their study, the authors also restricted the list to those journals subscribed to by their library, reasoning that this list constitutes the core journals in the field. ${ }^{12}$

The authors then surveyed the current editors of the twenty-two remaining journals, asking them to comment on their manuscript submission and acceptance rates, what they perceived as the quality of submissions, what criteria they used to select manuscripts, and how they felt about library literature in general.

The next step was to select the four most current issues of the twenty-two journals and, guided by the title indicated, systematically choose the first author holding an academic library position. If no such author appeared in a particular issue, that issue was rejected and the next most recent issue was used. The authors of the study wanted to contact those authors who had published recently, reasoning that they would more easily recall most of the events surrounding their efforts to get published and thus would be able to respond to the survey more accurately. Therefore, the authors of the study restricted the search to a three-year period of journal publication. If they were unable to find four authors who appeared to hold academic positions within that three-year period, they would survey only the number they could locate. Surveys were then sent to seventy-eight authors.

The journal authors were asked questions designed to coordinate with those asked of the journal editors. Specifically, they were asked about why they published, whether they perceived pressure to publish, whether publishing affected personnel decisions at their institution, how successful they had been in publishing, and how they felt about what appeared in library literature.

The response rates were 64 percent for editors and 73 percent for authors. 


\section{Authors' Responses}

The authors of the study had hoped that by randomly choosing authors to survey from among journals aimed at academic libraries, the results would reflect a broad cross section of these professionals. However, the results instead showed a highly select group of authors.

Given that the survey looked at academic library journals, it was not surprising that most of the authors have faculty status $(74 \%)$, and a majority $(60 \%)$ are on the tenure track (see table 1). But within this select group, the survey revealed additional characteristics. Those publishing are frequent contributors to the literature, with an average 8.8 of 9.3 articles submitted over the past five years accepted for publication. Moreover, several authors were solicited for articles by journal editors. Thus, the statistics would indicate an elite group of authors who appear frequently in the literature, sometimes because they are solicited by journal editors. Because of their publishing success rate, this group plays a crucial role in influencing the direction of the profession and the content of library literature.

This conclusion is supported by comments made by several of the authors who responded to the survey. They complained that there are too few authors doing most of the publishing (and their names repeatedly surface in the literature), leaving little room for what one respondent called "young blood." One author related this issue to the overall quality of library literature, arguing that there was little chance to improve quality as long as the same people are published again and again.

The authors surveyed were motivated to publish because of employment requirements and the desire to establish themselves in the profession. As table 1 shows, nearly 80 percent said that publishing was a requirement for promotion and tenure. Forty-six percent indicated that publishing affected salary increases. Sixtyone percent felt some or much pressure to

\begin{tabular}{|lc|}
\hline \multicolumn{2}{|c|}{ TABLE 1 } \\
\multicolumn{1}{|c|}{$\begin{array}{c}\text { Summary Statistics on } \\
\text { Author Respondents }\end{array}$} \\
\hline \hline Characteristic & $\%$ of total \\
\hline Have faculty status & $74 \%$ \\
On the tenure track & 60 \\
$\begin{array}{l}\text { Publishing is a requirement } \\
\text { for promotion }\end{array}$ & 79 \\
Publishing is a requirement \\
for tenure
\end{tabular}

publish, with 20 percent reporting constant pressure. Although many librarians felt pressured to publish in order to get promoted, attain tenure, and receive salary increases, the majority were motivated internally by a desire to establish a professional reputation. An almost equal number stated that peer pressure from colleagues motivated them to publish.

Despite pressure to publish-applied both internally and externally-few librarians worked for institutions with written policies specifying how much time employees could spend on research. Only 19 percent of the authors indicated their institution had such a policy, with an average of four hours per week allowed for research. Even librarians working for institutions with formal policies on release time found the time for research lacking. One author noted that although librarians were permitted four hours each week, this was "theoretic, not a reality on any regular basis." Another who reported having two to three hours each week for research commented: "Obviously, this time alone is nowhere near adequate to sustain a significant publishing record." On a more positive note, 64 percent indicated their institutions supported their research by other means such as funding, clerical assistance, or equipment.

In selecting journals to submit articles to and topics for research, the authors appeared to be most motivated by professional concerns and personal interest. 


\begin{tabular}{|lc|}
\hline \multicolumn{2}{|c|}{ TABLE 2 } \\
\begin{tabular}{|l} 
Reasons Revisions Made to \\
Articles As Reported \\
by Authors-Ranked
\end{tabular} \\
\hline \hline Reason for & $\begin{array}{c}\text { No. of Authors } \\
\text { Reporting }\end{array}$ \\
Revisions & 29 \\
To clarify points & 16 \\
To improve style (grammar, & \\
spelling, usage) & 3 \\
To change emphasis & 2 \\
To correct citations & 1 \\
To improve methodology & 0 \\
To correct factual errors & 12 \\
Other & \\
\hline
\end{tabular}

Most selected a journal because it was one of the top publications in the field. Only 12 percent admitted that their primary motivation for selecting a particular journal was because they felt their article was likely to be accepted. No respondent said that the main reason was that his or her article had been rejected by another journal and that the selected journal would likely publish it. Of the reasons for choosing the particular topic, 39 percent said their primary motivation was their perception of a lack of research in the area. This was followed closely by personal interest. Only 3 percent said they chose the topic because they felt it would be accepted by a journal. From these statistics, one can conclude that, although pressured to publish, few librarians resorted to taking the easy road in choosing either a topic or a journal. Equally true, however, is the fact that with an average acceptance rate of 94 percent reported by these authors, they may have little reason to be concerned about getting their articles published.

In addressing the issue of quality, most authors reported that the quality of both the article and the journal was judged by their peers and superiors when publishing affected personnel evaluations. Most also said quality was judged by peer evaluation inside as well as outside the institution. However, 23 percent said their institution had no formal methods for judging quality of either the article or the journal in which it was published.

The quality of author submissions appears to be high. Only 9 percent of authors reported that the article eventually published had been rejected previously by another journal. Sixty-three percent said that no extensive revisions were required by the journal editor, and only one author was required to rewrite more than 50 percent of the article submitted for publication. Table 2 shows that most revisions were needed to clarify points. It also shows that correction to grammar, spelling, and usage was the second mostcited reason for revisions.

Yet, despite the apparent quality of submissions as evidenced by low rejection rates and few required revisions, a majority felt the standards for publishing in the field were less rigorous than in other academic disciplines. None of the authors felt the standards were more rigorous, although many indicated they were as rigorous as in other academic fields. Yet about an equal percentage of both authors and editors $(43 \%$ and $40 \%$, respectively) indicated that library publishing involves the same rigor as other disciplines (see table 3).

In their comments, some of the authors noted that the quality of library literature has improved in recent years, but is still not on a par with other academic disciplines. Others clearly perceived the quality of publishing in library literature as inferior. One stated that the majority of library literature should be "stillborn," and some journals serve as vanity presses for librarians who need to publish. Another stated: "Library scholarship is an oxymoron." But another responded on a more positive note, expressing hope that librarians would begin to publish in other disciplines.

The subject matter of library journal articles also came under criticism by the authors. One felt that some subjects, par- 


\begin{tabular}{|c|c|c|}
\hline \multicolumn{3}{|c|}{$\begin{array}{c}\text { TABLE } 3 \\
\text { Comparison of Authors' } \\
\text { and Editors' Experiences } \\
\text { and Perceptions }\end{array}$} \\
\hline $\begin{array}{l}\text { Experiences/ } \\
\text { Perceptions }\end{array}$ & Authors & Editors \\
\hline $\begin{array}{l}\text { Percentage of articles } \\
\text { accepted/accept }\end{array}$ & $94 \%$ & $48 \%$ \\
\hline \multicolumn{3}{|l|}{$\begin{array}{l}\text { Extent of revisions made } \\
\text { to manuscripts }\end{array}$} \\
\hline Very extensive & 2 & 18 \\
\hline Somewhat extensive & 6 & 12 \\
\hline Not extensive & 30 & 64 \\
\hline None & 63 & 9 \\
\hline \multicolumn{3}{|l|}{$\begin{array}{l}\text { Perceived rigor of library } \\
\text { publishing compared to } \\
\text { other fields }\end{array}$} \\
\hline More rigorous & 0 & 0 \\
\hline Less rigorous & 57 & 60 \\
\hline Same rigor & 43 & 40 \\
\hline
\end{tabular}

ticularly technology, were overemphasized at the expense of articles on topics such as history or social issues. Another stated: "I would like to see more substantial articles about library concerns and fewer about frivolous areas such as faculty status." The debate about quantitative versus qualitative research was mentioned by another respondent, who felt that, until recently, library journals emphasized the former.

\section{Editors' Responses}

Journal editors play a crucial role in influencing what appears in library literature. Although many editors have the assistance of editorial boards, as individuals they exert power over authors-and the profession-in their role as determiners of what is published. Yet, there has been little discussion of the role played by editors in shaping the professional literature. In researching this article, the editors of the journals surveyed were asked questions designed to coordinate with those asked of the authors in order to draw comparisons.

The results of the survey showed that journal editors are a stable group. On average, they have served in their positions for more than six years (see table 4), with the actual numbers ranging from two to thirteen years. This indicates a stability (some might argue a stagnation) among the referees of library literature. In a profession changing as rapidly as librarianship, an editorship lasting an average of six years can have a major influence on the dissemination of professional ideas and the direction of scholarship.

Most editors (71\%) have editorial boards to assist them in deciding whether an article is to be published. This would appear to open up the manuscript selection process, but such statistics do not tell the whole story. Sixty percent of those with editorial boards noted that one reason editorial board members are selected is because they are colleagues of either the editor or another board member. One hundred percent said a reason board members are chosen is because of their professional reputation or previous publications, which again indicates a self-se-

\begin{tabular}{|c|c|}
\hline \multicolumn{2}{|c|}{$\begin{array}{c}\text { TABLE } 4 \\
\text { Summary Statistics on } \\
\text { Editor Respondents }\end{array}$} \\
\hline Characteristic & $\begin{array}{l}\text { \%/avg. } \\
\text { of total }\end{array}$ \\
\hline Average tenure as editor & 6.1 years \\
\hline Have editorial boards & $71 \%$ \\
\hline \multicolumn{2}{|l|}{$\begin{array}{l}\text { Editorial boards selection } \\
\text { based on: }\end{array}$} \\
\hline Professional reputation & $100 \% *$ \\
\hline Previous publications & $50 \% *$ \\
\hline $\begin{array}{c}\text { Professional colleagues } \\
\text { of editor or board }\end{array}$ & $60 \% *$ \\
\hline Elected by profession & $0 \% *$ \\
\hline Other & $40 \% *$ \\
\hline \multicolumn{2}{|c|}{$\begin{array}{l}\text { * Because editors indicated all applicable } \\
\text { reasons for selecting editorial board } \\
\text { members, these percentages equal more than }\end{array}$} \\
\hline
\end{tabular}




\begin{tabular}{|c|c|}
\hline \multicolumn{2}{|c|}{$\begin{array}{c}\text { TABLE } 5 \\
\text { Top Reasons for Accepting } \\
\text { Manuscripts As Reported } \\
\text { by Editors-Ranked } \\
\end{array}$} \\
\hline $\begin{array}{r}\text { No. of Editors } \\
\text { Reason to Accept }\end{array}$ & Reporting \\
\hline $\begin{array}{l}\text { Relevance of subject } \\
\text { to audience }\end{array}$ & 10 \\
\hline Well written & 9 \\
\hline Thoroughness of article & 5 \\
\hline $\begin{array}{l}\text { Fills void in professional } \\
\text { literature }\end{array}$ & 4 \\
\hline Validity of results & 4 \\
\hline Perceived as a seminal work & 4 \\
\hline New/novel treatment of subject & 3 \\
\hline Timeliness & 2 \\
\hline Professional appearance & 0 \\
\hline $\begin{array}{l}\text { Guidelines for submissions } \\
\text { followed }\end{array}$ & 0 \\
\hline Title of manuscript & 0 \\
\hline High quality of abstract & 0 \\
\hline $\begin{array}{l}\text { Qualifications of authors to } \\
\text { write on subject }\end{array}$ & 0 \\
\hline Controversial subject & 0 \\
\hline Other & 3 \\
\hline
\end{tabular}

lected group. Those with opinions recognized by the profession through either reputation or publication are also making decisions on which manuscripts are to be published in the literature. No respondent indicated that editorial board members are elected by a democratic voting process that might include a large pool of diverse applicants. Only 14 percent of respondents indicated a desire to select members who offered the board a geographical or professional specialization balance.

Editors have a big job to do reviewing articles. On average, those responding received sixty manuscripts per year, from which they accepted twenty-nine for publication. However, the acceptance rate reported by the editors is quite different from that reported by the authors publishing in these journals. (The authors reported an average acceptance rate of 94 percent.)
Despite the fact that editors said they only accepted 48 percent of the manuscripts submitted, most $(80 \%)$ felt the overall quality of submissions was good, with none indicating the quality as poor.

The survey asked the editors to select from a list and rank the top three reasons for accepting or rejecting a manuscript. As shown in table 5, the reason most often given for acceptance was relevance to the journal's audience (ranked as one of the top three reasons by ten of the fourteen respondents). The apparent lesson for authors is to choose the outlet for their intended publications carefully. The second most popular reason for acceptance (cited by nine of the fourteen editors) was that the article was well written and clear in thought and style. Therefore, authors should be advised to spend time revising their articles for clarity and style before submitting them for publication.

Less important to the editors was the subject matter of manuscript submissions. For example, filling a perceived void in the professional literature or being a seminal work in the field was reported by each of four editors as a reason for accepting a manuscript for publication. An article with a controversial topic was listed by no editor as a top reason for acceptance, and introducing a new or novel treatment of a subject was cited by just three. These findings appear to indicate a prevailing conservative attitude among journal editors.

One surprising revelation is that only four editors ranked the validity of research results as one of the three primary reasons to accept an article. And no editor felt that the author's qualifications to write on the topic was a reason to accept a manuscript. The fact that author qualifications were of little importance to editors and research results were not routinely validated signals the potential for poor-quality professional literature.

Among the lowest-ranked reasons for accepting manuscripts were professional appearance, guidelines for submissions 
followed, title of manuscript, and high quality of abstract.

In ranking reasons for rejecting an article, only three editors cited factual inaccuracy and no one cited a lack of author qualifications (see table 6). This would appear to confirm the potential for poorquality research in the literature, especially when, for example, only one editor reported finding frequent factual errors in articles received.

On the plus side, however, ten editors stated that shallow research and nine stated that topics not relevant to the journal's audience were among the top reasons for rejecting an article for publication. Eight indicated that poorly written articles were grounds for rejection. Those reasons the editors ranked lowest for rejecting a manuscript included author guidelines not followed, unprofessional appearance, and title of manuscript.

Most journal editors have staffs to assist them in editing accepted articles. However, most articles are not extensively rewritten: 63 percent of editors stated that only between 10 and 30 percent of articles are rewritten. Only two editors commonly rewrote more than 50 percent of an article. These statements are supported by the experiences of the authors surveyed (see table 3 ).

Most editors saw no relationship between pressure on authors to publish and quality of manuscripts received. Only one admitted accepting articles because the journal lacked submissions to fill an issue. However, as the results from the authors' survey indicate, some editors solicit articles, which may be one way to fill incomplete issues, even if this is not viewed as such by editors.

\section{Conclusions}

The results of the survey of both authors and editors reveal some troublesome trends in academic library publishing and their impact on overall quality.

The survey revealed that librarians feel pressured to publish, for both per-

\begin{tabular}{|c|c|}
\hline \multicolumn{2}{|c|}{$\begin{array}{c}\text { TABLE } 6 \\
\text { Top Reasons for Rejecting } \\
\text { Manuscripts As Reported } \\
\text { by Editors-Ranked } \\
\end{array}$} \\
\hline Reason to Reject & $\begin{array}{l}\text { Jo. of Editors } \\
\text { Reporting }\end{array}$ \\
\hline Shallow, poor research & 10 \\
\hline Not relevant to audience & 9 \\
\hline Poorly written & 8 \\
\hline Article shallow & 6 \\
\hline Sheds no new light on topic & 5 \\
\hline Inaccuracy of facts & 3 \\
\hline Outdated subject & 0 \\
\hline Author guidelines not followec & 0 \\
\hline Unprofessional appearance & 0 \\
\hline Title of manuscript & 0 \\
\hline Subject too controversial & 0 \\
\hline $\begin{array}{l}\text { Authors lacks qualifications } \\
\text { to write on topic }\end{array}$ & 0 \\
\hline Other & 2 \\
\hline
\end{tabular}

sonnel (for promotion, tenure, and raises) and personal reasons (a desire to establish themselves in the profession). This result is confirmed by other studies of scholarly communication conducted in the past which have shown that faculty in other disciplines have three incentives to publish: "the desire to disseminate knowledge, the desire for membership, and the desire for priority." ${ }^{13}$ However, the survey revealed that, unlike most faculty members who work flexible hours and have nine-month contracts and research assistants, librarians generally enjoy little support for research. Although they are pressured to engage in research and to publish, they must do so while working a forty-hour week, twelve months a year. The difficulty in finding time for research is compounded by developments in the profession that require librarians to keep current on the ever-changing technology. Within such constraints, how can librarians find time for intense, in-depth, and long-term research? Quality is certain to be affected. 
Another trend revealed by the survey is that for better or worse, academic library literature is dominated by a small group of elites as both authors and longtenured editors. This trend is the same in other fields as well. A 1983 study by Stephen Cole of publishing in the scientific professions indicated that the editors of these professional journals are its elites, and these gatekeepers act to produce and maintain consensus in the profession. ${ }^{14}$ The authors' survey revealed that editors have average tenures of six years, and were chosen as editors because of their previous publication record or professional reputation. Furthermore, these gatekeepers may not actively seek out controversial, timely, or pivotal works. Indeed, they select many of the same authors for publication, as evidenced by those re-

\section{An article with a controversial topic was listed by no editor as a top reason for acceptance. ...}

sponding to this survey who have an average submission acceptance rate of 94 percent. Editors are chosen because they are established authors, and they in turn select other established authors for publication. Thus, consensus is produced and maintained when the same editors select the same authors.

A distressing finding of the survey is the apparent lack of interest paid by editors to the accuracy of what is being published and to the qualifications of an author to write on a chosen topic. In scientific literature, research results are carefully screened, methodologies reviewed, and peer commentary used to judge the merits of research both before and after publication. Library literature, however, is not subjected to such systematic scrutiny. It may be that in a blind review process, it is difficult to assess an author's qualifications; however, the review process is not completely blind. Some editors solicit articles from specific authors.
Even when articles are unsolicited, editors are privy to the names and professional titles of manuscript contributors. Blind reviewers can judge the qualifications of the author to write on a subject through a careful review of the manuscript with a particular eye toward whether the author relates any professional experiences with the chosen topic. The problem of unqualified authors is compounded when editors do not check for factual errors in manuscripts they accept.

The consequence of all these trends is that the quality of academic library literature suffers. This conclusion is supported by the statements of editors and authors alike. Authors, many of whom were quite successful in getting articles into print, felt that the quality of the literature was not on a par with other fields. Editors were more willing to say the manuscripts they receive from authors were of good quality. However, neither group felt that the library profession had more rigorous standards for publishing than other fields.

The conclusions drawn from this survey represent only a select population. An additional study of those academic librarians who have never published might shed more light on what is appearing (and what is not appearing) in the professional literature and why. Another survey might look for correlation between specific job responsibilities of librarians and success rates in publishing to determine if some positions are more conducive to research and publication.

\section{Improving Quality}

How might the quality of library literature be improved? The authors propose six suggestions:

\section{Release time}

Library administrators must take an interest in improving the profession's literature by providing release time to their faculty members to conduct research. Because publishing is weighted heavily in personnel decisions, libraries should have 
written policies that specify release time for librarians to conduct research. It is not enough to grant an occasional day. Highquality scholarship requires sustained efforts, with sufficient time to develop ideas, think through methodologies, and write and revise. It cannot-and should not-be done in competition with other daily job responsibilities.

The survey showed that many libraries where librarians have faculty status have neglected an important facet of ACRL's "Statement on Faculty Status of College and University Librarians" as issued in 1972. The statement reads: "Faculty status entails for librarians the same rights and responsibilities as for other members of the faculty. They should have corresponding entitlement to rank, promotion, tenure, compensation, leaves, and research funds." ${ }^{15}$ Most universities seem to have neglected this important point. The survey revealed that few libraries have research leave policies.

A 1990 article about library faculty at Auraria Library, in Denver, reported on policies instituted there to assist faculty with research. ${ }^{16}$ Among the most important factors in successful research and publication at Auraria was the opportunity to take release time for extended periods. Other policies of that library that have resulted in an increase in scholarly activity include: giving priority for travel funds to those presenting papers at conferences; allocating money to faculty members for research support services; and developing a research center where information on scholarly publishing (including publication guidelines) is collected and available. All these policies promote the production of scholarly works by library faculty, and should be seriously considered by all library administrators if publishing is to continue to be important to library faculty careers and the profession as a whole.

\section{Evaluating Quality}

If publications are to be a part of a librarian's personnel review, their qual- ity also must be evaluated. An assessment of quality should include, among other things, the reputation of the journal, the relevance of the chosen topic to the profession, the pertinence of the work to the faculty member's role in the library, whether or not the work is a seminal piece, the significance of the findings, and whether the article fills a void in the body of knowledge. Methods for judging publications similar to those used by some other colleges (outside peer review, for example) should be applied to library publications. It is not enough to simply count the number of publications.

\section{Qualified Authors}

Because librarianship is becoming so specialized, those who publish should have the appropriate background knowledge of the subject area, including professional experiences related to that area. Editorial board members should try to judge the qualifications of persons contributing manuscripts, even in a blind review process. A rigorous manuscript review process, for example, should ferret out those whose methodology and results reveal a

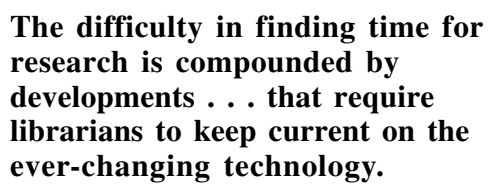

lack of expertise in the area they write about. And those who evaluate the quality of publications during personnel evaluations must also take into consideration the qualifications of the author. Once accepted, editorial staffs should check articles for factual errors prior to publication.

\section{Opening up the Process}

The library profession should take a renewed interest in its scholarship and strive to increase the number of persons engaged in the publishing process. 
Methods to open up the publishing process to greater numbers might include: shortening tenures for editors; finding more democratic ways to select editors and editorial board members; finding ways to identify new authors; demanding quality and accuracy in the literature; and accepting more manuscripts with controversial subjects. As readers, we must turn a critical eye to what we read in the literature, and if articles are poor in quality or inaccurate, we must voice our concerns. More of us must also be willing to offer our own manuscripts for publication, especially if we have not published before, and aim for the highest quality in those manuscripts. Longev-

\section{More of us must also be willing to offer our own manuscripts for publication, especially if we have not published before. . . .}

ity may have its merits, but editors may want to consider imposing term limits on themselves as one way to avoid stagnation and open up the publishing process.

\section{Student Training}

The authors of this article urge library schools to teach students research methodology and writing skills, if they are not currently doing so. These skills provide students with the foundation upon which to engage in research and publication in their professional careers. For librarians with faculty status, the ability to research and publish is essential to succeeding in academe.

\section{Publishing Outside the Field}

One of the most interesting suggestions the authors received from those surveyed was one that encouraged librarians to publish outside the field of librarianship. The authors agree with the respondent who felt librarians should apply their knowledge to other academic fields. This would demonstrate to others that librarians can publish on a par with their teaching colleagues, and it would improve the image of librarians. Publishing in other fields in which one has some expertise would do much to elevate the status of librarians, enabling others to see that librarians have an important role to play in the advancement of scholarship.

\section{Notes}

1. W. Bede Mitchell and L. Stanislava Swieszkowski, "Publication Requirements and Tenure Approval Rates: An Issue for Academic Librarians," College \& Research Libraries 46 (May 1985): 249-55.

2. William K. Black and Joan M. Leysen, "Scholarship and the Academic Librarian," College \& Research Libraries 55 (May 1994): 229-41.

3. For a discussion of the historical development of research and scholarship in academe, see Ernest L. Boyer, Scholarship Reconsidered: Priorities of the Professoriate (Princeton, N. J.: Carnegie Foundation for the Advancement of Teaching, 1990).

4. Ibid., 12.

5. Oscar Handlin, as quoted in Dennis P. Carrigan, "Publish or Perish: The Troubled State of Scholarly Communication," Scholarly Publishing 22 (Apr. 1991): 132.

6. Carrigan, "Publish or Perish," 132.

7. Boyer, Scholarship Reconsidered, 32.

8. Statistics through 1989 as reported in Charles B. Lowry, "The Status of Faculty Status for Academic Librarians: A Twenty-Year Perspective," College \& Research Libraries 54 (Mar. 1993): $163-72$.

9. Emily Werrell and Laura Sullivan, as quoted in Black and Leysen, "Scholarship and the Academic Librarian," 230.

10. Mitchell and Swieszkowski, "Publication Requirements and Tenure Approval Rates," 249.

11. Criteria for awarding promotion, tenure, and merit raises have changed in recent years for librarians at the University of Toledo as a result of collective bargaining representation by the 
American Association of University Professors. In 1993, salaries for librarians became comparable to those of teaching faculty as a result of librarians being a part of the bargaining unit. The criteria for judging the performance of librarians has since come under closer scrutiny by the administration.

12. The journals surveyed for this study were as follows: American Archivist, American Libraries, Collection Management, College \& Research Libraries, Conservation Administration News, Government Information Quarterly, Information Processing and Management, Journal of Academic Librarianship, Journal of Education for Library and Information Science, Journal of Library Administration, Journal of the American Society of Information Science, Library Acquisitions: Practice and Theory, Library and Information Science Research, Library Hi Tech, Library Software Review, Library Trends, Rare Books \& Manuscripts Librarianship, References Services Review, Research Strategies, Serials Review, Special Libraries, and Technicalities.

13. Carrigan, "Publish or Perish," 133.

14. Stephen Cole, as cited in Lowell L. Hargens, "Scholarly Consensus and Journal Rejection Rates," American Sociological Review 53 (Feb. 1988): 139. "Cole claims that all scholarly fields face similar functional problems and, therefore, have similar elite structures, and that this, in turn, produces similar levels of consensus at the "research frontiers' of different disciplines."

15. "Statement on Faculty Status of College and University Librarians," as reprinted in Faculty Status for Academic Librarians: A History and Policy Statements, compiled by the Committee on Academic Status of the Association of College and Research Libraries (Chicago: ALA, 1975), 3538.

16. Kathleen Kenny, Linda D. Tietjen, and Rutherford W. Witthus, "Increasing Scholarly Productivity among Library Faculty: Strategies for a Medium-Sized Library," Journal of Academic Librarianship 16 (Nov. 1990): 276-79. 